\title{
The Best and the Worst: TEFL Experts' Opinions of the Most and the Least Important Predictors of Situational Willingness to Communicate
}

Marzieh Rafiee ( $\nabla$ rafieemarzieh@gmail.com )

Islamic Azad University https://orcid.org/0000-0002-3732-4258

Salman Abbasian Naghneh

Islamic Azad University

\section{Original article}

Keywords: Second language willingness to communicate (L2WTC), Situational properties, Best-worst method, Multiple-criteria decision-making methods

Posted Date: September 14th, 2021

DOl: https://doi.org/10.21203/rs.3.rs-812306/v1

License: (c) (i) This work is licensed under a Creative Commons Attribution 4.0 International License.

Read Full License 
The Best and the Worst: TEFL Experts' Opinions of the Most and the Least Important Predictors of Situational Willingness to Communicate

\title{
Marzieh Rafiee
}

Department of English, Najafabad Branch, Islamic Azad University, Najafabad, Iran rafieemarzieh@gmail.com

Salman Abbasian-Naghneh

Department of Mathematics, Najafabad Branch, Islamic Azad University, Najafabad, Iran $\underline{\text { Salman_abasian@yahoo.com }}$

\section{Corresponding author bio}

Marzieh Rafiee, $\mathrm{PhD}$ teaches in the English Language Department at the Islamic Azad University of Najafabad, Isfahan, Iran. She has taught courses of variegated character, including academic and advanced writing, language learning skills and computer mediated language learning, for years. She is the author of a number of books in this respect as well. She has also published a good number of articles on academic writing, contrastive rhetoric and language learning skills in local and international journals. Her current research interests include critical contrastive rhetoric, EFL learners' willingness to communicate and e-learning education.

\begin{abstract}
The current study aimed to identify the most and the least important situational properties of second language willingness to communicate (L2WTC) in an EFL context. After reviewing the related literature, 24 influencing factors were identified and then they were prioritized. Ninety TEFL experts participated in the study to answer the research questionnaire. A quantitative research approach applying paired comparison questionnaire was employed. Data analysis was done using Excel spreadsheet for sorting data and calculating the mean and WinQSB software for solving linear programming model. The results showed that, among the selected variables, "the size of the group", "familiarity with topics under discussion", and "interlocutors and familiarity with them" were determined to be the first most important
\end{abstract}


situational variables which highly influence L2WTC. The findings also showed that "attitudes toward the learning situation", "course evaluation criteria" and "alignment with the classroom norms" were the least important factors influencing L2WTC. The significance of the study lies in its theoretical contributions and pedagogical implications it has for the field of second language teaching and learning.

Keywords: Second language willingness to communicate (L2WTC); Situational properties; Best-worst method; Multiple-criteria decision-making methods

\section{Introduction}

The important influential properties of second language willingness to communicate (L2WTC) have long been a question of great interest in the field of modern language instruction and L2 communication. In the last few decades, for instance, there has been a surge of interest in finding the key social, situational, psychological and other predicators of L2WTC. As stated in the literature, there are many factors which influence language learners' L2WTC (Cao, 2011; Kang, 2005). These properties include, but not limited to trait-like (or individual), situational, social, motivational, factors related to the influence of teachers over learners and so forth. Furthermore, especial attention has been given to finding the most prominent individual predicators and their prioritization (Rafiee \& Abbasian-Naghneh, 2018). However, to the best of researchers' knowledge, there has been no attempt in finding the most desirable and the most important predispositions of situational L2WTC. Furthermore, the nature of the least desirable situational properties of L2WTC is still unclear. To achieve that goal, a decision-making method can be used whose major purpose is "identifying and selecting an alternative from a set of alternatives based on the preferences of the decision-maker(s)" (Rezaei, 2016, p. 126). 
As the sub-discipline of operation research, multiple-criteria decision-making (MCDM), or multiple-criteria decision analysis (MCDA), deals with evaluating multiple conflicting criteria. In the simple sense, decision-making is the act of choosing between two or more different alternatives. As stated by Mardani, Jusoh, and Zavadskas (2015), MCDM has been considered to be an active research area since 1960 which produced many theoretical and applied research articles and books across many disciplines. Since this is a method which helps people making decisions based on their preferences, especially when there are more than one conflicting criteria (Ho, 2008), it is preferred to other operation research methods. One of the most recently developed areas in MCDM is the best-worst method (BWM), a comparison-based method whose main concern is to conduct the comparisons in a structured way. The advantages of this method are that, not only less amount of information is required, but the comparisons are also more uniform and consistent (Rezaei, 2016).

The primary aim of this paper, therefore, is finding the least and the most important situational properties of L2WTC in EFL context of Iran by applying best-worst method (BWM). This is the first study which applies one of the most developed methods of MCDM to compare the criteria related to L2WTC in a structured way. Hence, it is hoped that this research will contribute to a deeper understanding of the nature of WTC in second language communication.

\section{Theoretical background}

\section{Situational properties of L2WTC}

A growing body of evidence suggests that the social environment of the classroom has great influence on the behavior and thinking of language learners in the classroom (Jennings \& Greenberg, 2009). As a new perspective, the proponents of this line of thinking challenge the perspective that views L2WTC as the individual or trait-like predisposition. 
The new perspective was well approved by different research studies and lead to the change of the definition of L2WTC which was provided earlier. Accordingly, L2WTC was defined as "a readiness to enter into discourse at a particular time with a specific person or persons, using L2" (MacIntyre, Dörnyei, Clément, \& Noels, 1998). The immediate situational antecedents which were supposed to influence L2WTC included, but not limited to, the state of communicative self-confidence, willingness to communicate with a particular person, intergroup attitudes, interpersonal motivation, self-confidence, communicative competence, social situation, personality and intergroup climate (Kang, 2005).

Following this view, the researchers tried to find the ways L2WTC can be affected by situational variable. MacIntyre, Baker, Clément, and Conrod (2001) found that social support, especially from the friends, impacted L2WTC outside the language classrooms. In comparing the immersion and non-immersion programs, Baker and MacIntyre (2000) and MacIntyre et al. (2001) found that WTC was influenced by the educational context. As explained by Yashima (2012), immersion contexts are similar to L1 situations wherein anxiety is perceived to be the best predictor of WTC. J. E. Peng and Woodrow (2010) also examined the role of classroom environment on L2WTC and found that, in Chinese English learning context, a variety of factors such as communication confidence, learner's beliefs, classroom setting, motivation and the likes, affect WTC. Among these variables, confidence was found to be the most significant predictors of WTC. In a more recent attempt, Syed and Kuzborska (2018) highlighted the influence of contextual factors, such as teacher, topic and task type on L2WTC. The data, which was gathered from different sources (classroom observation, learners' diaries, biographic questionnaires and stimulated recall interviews) revealed that language learners' L2WTC was strongly influenced by the learners' interest in topic, task type, teachers' behavior, the interactional context and the classroom environment. 
Although extensive research has been carried out on L2WTC, studies which determined the most and the least desirable situational properties of L2WTC have been scarce. So far, the

priority of researchers in the field was to identify the influential variables of L2WTC construct. In this regard, throughout the recent two decades, many trait-like and situational properties of WTC were explored by researchers. Besides, no research has been found that surveyed the preference of one property over the other one/s from the viewpoints of experts in the field. Therefore, this research seeks to address the following questions:

- What are the situational factors affecting L2WTC in the related literature?

- What is the most important L2WTC situational property?

- What is the least important L2WTC situational property?

\section{Methodology}

\section{Sampling}

The statistical population of the study consisted of the EFL experts who had the academic PhD degree in TEFL. Moreover, they must have teaching experience of more than 10 years in English communication classrooms. Based on these conditions, there were a total of 90 participants (89\% male; $M$ age $=40.5 S D=5.9$ ), all TEFL university professors at different universities in Iran. Participants represented a wide range of teaching experience; $27.7 \%(n=25)$ had teaching experience between 10 to 15 years, $41.1 \%(n=37)$ had the teaching experience of 15 to 20 years and $31.1 \%(n=28)$ had the experience of above 20 years. The researchers gave the research questionnaires to some participants through email because the access to some participants was difficult. Before beginning the study, the participants were provided with adequate information about L2WTC and the situational 
factors affecting it. Furthermore, the participants were given information about the way they should fill the questionnaire.

\section{Instrument}

Data collection instrument in this study was a pairwise comparison questionnaire (see Appendix A) which is often used to compare alternatives in pairs to judge which entity has greater quantitative property or is preferred over others. Applying this questionnaire gives the researcher the possibility to decide how to access the alternatives by providing a simple way to rank and rate them. To rate the importance of the options concerning the other options, measures from 1 to 9 are used in this questionnaire. Aiming to check the reliability of the comparison, the following formula was applied to measure the consistency rate of the questionnaire. Measuring the consistency rate in BWM and AHP is structurally similar.

$$
\text { Consistency rate }=\frac{\xi^{*}}{\text { Consistency index }}
$$

\section{Best-worst Multi-Criteria Decision-making Method}

As firstly introduced by Rezaei $(2015,2016)$, Best-worst Method (BWM) is a type of multi-criteria decision-making method whose aim is ranking and selecting an alternative among a set of alternatives. This method, which is commonly used in various fields including health, economics, engineering, IT and many others, is applied by one or a group of decisionmakers. The distinctive feature of this method, compared with other decision-making methods such as AHP, is that it needs less comparison data and results in more consistent comparisons (Rezaei, 2015). This indicates that it produces more trustworthy results. Therefore, the number of paired comparison in AHP with $n$ index equals $\frac{n(n-1)}{2}$, while in BWM, it equals $2 n-3$. For instance, in AHP method, 45 paired comparisons should be done for 10 indexes, while this number reduces to 17 in BWM. 
As a newcomer to the field of decision-making methods, BWM is an easy-to-apply and easy-to-understand MCDM method. This method does the comparisons in a structured way and brings in more understandable judgment. Above all, this method leads to more consistent comparisons with more reliable rankings and weigh (Ajrina, Sarno, \& Ginardi, 2018). As mentioned by Rezaei, Hemmes, and Tavasszy (2017), the interval weights of BWM allows the decision-makers to select a set of weights which are more consistent with their higher-level information. The other salient feature of this method is that it can be applied to different MCDM problems which have qualitative or quantitative criteria.

According to Rezaei (2015), several steps should be followed to determine the weights of criteria. In the first step, the set of decision criteria, which are necessary in decision-making, is determined. The set of criteria is defined as $\left\{c_{1}, c_{2}, \ldots, c_{n}\right\}$. In step 2 , the best (or the most important, the most desirable) and the worst (or the least important, the least desirable) criteria are determined. In the next step, the preference and priority of the best criterion over other criteria is determined by using a number from 1 to 9 . The best-to-other, or BO vector, would be $A_{B}=\left(a_{B 1}, a_{B 2}, \ldots, a_{B n}\right)$. In this vector, $a_{B j}$ means the priority of the best criterion (B) over criterion (j). It is apparent that $a_{B B}=1$. Similar to previous step, in step 4 , the priority or preference of all the criteria over the worst criterion is determined by using a number between 1 to 9. The others-to-worst, or OW vector, which is resulted would be $A_{W}=\left(a_{1 W}, a_{2 W}, \ldots, a_{n W}\right)^{T}$. In this vector, $\left(a_{j W}\right)$ reveals the preference of criterion (j) over the worst criterion (W). It is apparent that $a_{W W}=1$. In the last step, the optimal weights $\left(w_{1}^{*}, w_{2}^{*}, \ldots, w_{n}^{*}\right)$ are found. To do so, the following model should be solved:

$$
\min \xi
$$

$$
\text { s.t. }
$$

$$
\left|w_{B}-a_{B j} w_{j}\right| \leq \xi, \text { for all } j
$$




$$
\begin{gathered}
\left|w_{j}-a_{j w} w_{w}\right| \leq \xi, \text { for all } j \\
\text { s.t. } \sum_{j} w_{j}=1 \\
w_{j} \geq 0, \text { for all } j
\end{gathered}
$$

Solving the above model, the optimal weights of $\left(w_{1}^{*}, w_{2}^{*}, \ldots, w_{n}^{*}\right)$ and $\xi^{*}$ are obtained. Finally, in step 6 , the consistency rate is calculated. By using the obtained $\xi^{*}$, the consistency rate is calculated. It is clear that the bigger $\xi^{*}$ is, the higher the consistency ratio becomes. Consequently, it shows that the less reliable the comparisons might be. The consistency indexes using BWM are as follows:

\begin{tabular}{|c|c|c|c|c|c|c|c|c|c|}
\hline$a_{B W}$ & 1 & 2 & 3 & 4 & 5 & 6 & 7 & 8 & 9 \\
\hline $\begin{array}{l}\text { Consistency } \\
\text { index }\end{array}$ & 0.00 & 0.44 & 1.00 & 1.63 & 2.30 & 3.00 & 3.73 & 4.47 & 5.23 \\
\hline
\end{tabular}

BWM has been used in a variety of areas, including evaluation of the sustainability of supply chain (Ahmad, Rezaei, Sadaghiani, \& Tavasszy, 2017; Ahmadi, Kusi-Sarpong, \& Rezaei, 2017), evaluating service quality of airline industry (Gupta, 2018), identifying facilitators of innovation in technology (Gupta \& Barua, 2016), continuous evaluation of technologies (Ren, Liang, \& Chan, 2017) and supplier selection (Rezaei, Nispeling, Sarkis, \& Tavasszy, 2016).

\section{Procedure}

In reviewing the related literature, 24 situational factors were identified to be influential on L2WTC. A screening questionnaire (see Appendix B) was used to assess the degree of the importance of the situational variables affecting L2WTC. From among the situational factors which were identified in the literature, 10 were selected which had more influence on L2WTC. Since the data collection involved asking information from participants through distributing questionnaires, this study was characterized to be survey-type. By 
receiving the informed consents from the participants, the pair-wise comparison questionnaires were distributed among them. Pairwise comparison questionnaire is a way to assess how to achieve alternatives by providing a simple way to rank them. The questionnaire requires respondents to have full knowledge of the criteria and alternatives to compare them well (Ramik, 2017). The participants were given the sufficient time and instruction to fill out the questionnaires. From among the 90 participants who were selected purposefully, 82 TEFL experts answered the questionnaire. The response rate was $91 \%$. The consistency rate of all the questionnaires was high enough; therefore all the questionnaires were approved. Figure 1 illustrates the data collection procedure.

Figure 1

\section{Research procedure}

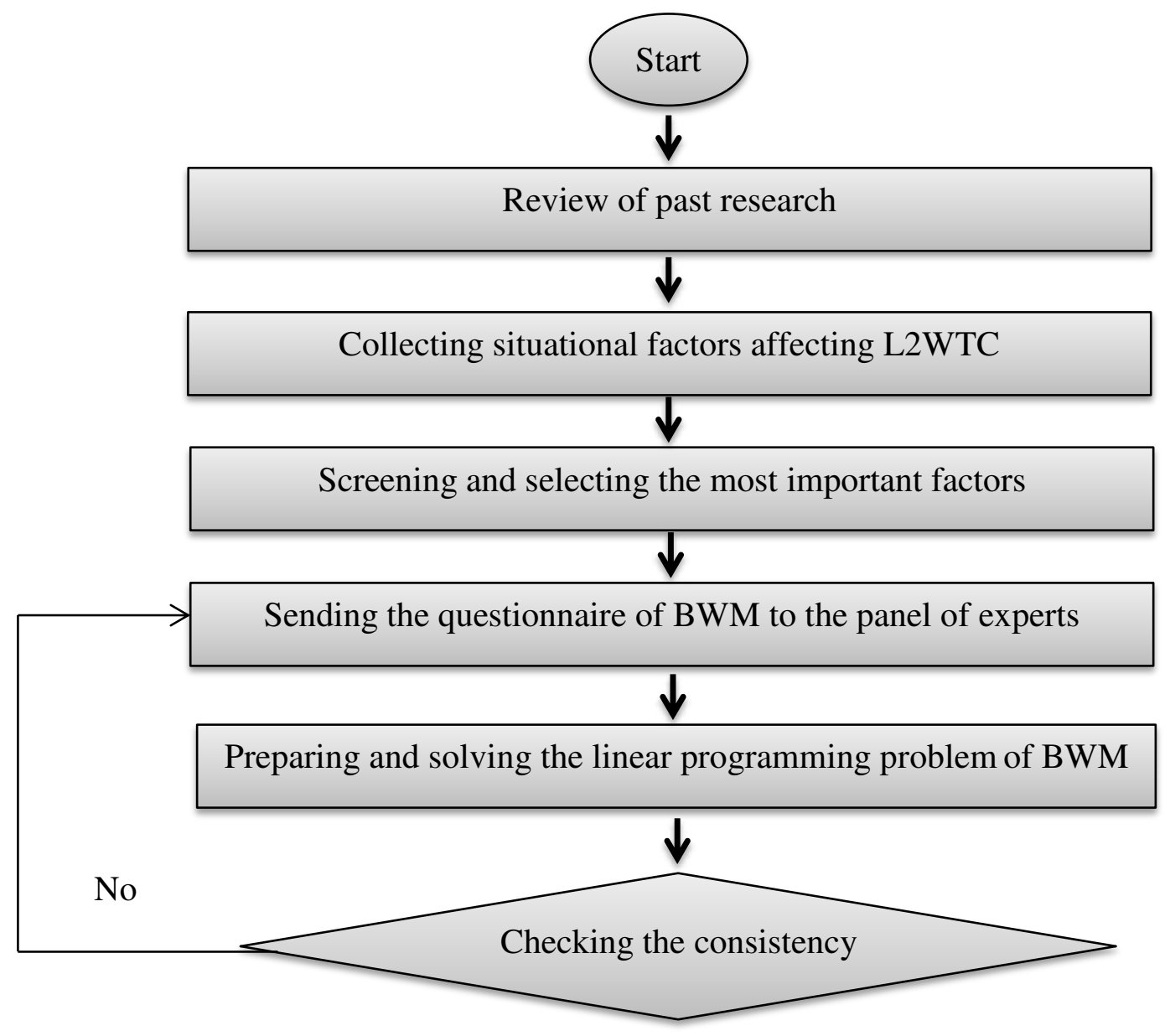


$\downarrow \quad$ Yes

Determine the relative importance of the factors

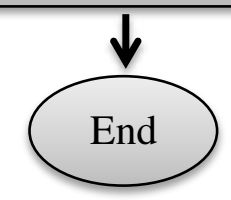

\section{Data analysis}

After collecting the questionnaires from the participants, the data was entered into the Excel spreadsheet. The geometric means were calculated and then the data was entered into the WinQSB software. This is a decision-making tool that is based on multi-criteria decision making.

\section{Results}

The first research question was formed to identify the situational variables affecting L2WTC reported in the literature. For this purpose, the related studies were reviewed and several factors were identified (see Table 1).

Table 1

Situational factors affecting L2WTC reported in the literature

\begin{tabular}{|c|l|l|}
\hline No. & \multicolumn{1}{|c|}{ Factors } & \multicolumn{1}{c|}{ References } \\
\hline 1 & instrumental orientation & Yu (2011) \\
\hline 2 & Task orientation & Dorman, Fisher, and Waldrip (2006) \\
\hline 3 & Where interactions occur & Yashima, Zenuk-Nishide, and Shimizu (2004) \\
\hline 4 & $\begin{array}{l}\text { Interlocutors and familiarity } \\
\text { with them }\end{array}$ & $\begin{array}{l}\text { Cao and Philp (2006); Kang (2005); Cao (2011); } \\
\text { Wen and Clément (2003) }\end{array}$ \\
\hline 5 & Context type & Barjesteh, Vaseghi, and Neissi (2012) \\
\hline 6 & participation & $\begin{array}{l}\text { Cao and Philp (2006); Kang (2005); Cao (2011); } \\
\text { Wen and Clément (2003) }\end{array}$ \\
\hline 7 & teaching style & Zarrinabadi (2014) \\
\hline
\end{tabular}




\begin{tabular}{|c|c|c|}
\hline 8 & $\begin{array}{l}\text { familiarity with topics } \\
\text { under discussion }\end{array}$ & $\begin{array}{l}\text { Cao and Philp (2006); Kang (2005); Cao (2011); } \\
\text { Wen and Clément (2003) }\end{array}$ \\
\hline 9 & class dynamism & Khatib and Nourzadeh (2015) \\
\hline 10 & The issue of time & MacIntyre et al. (1998) \\
\hline 11 & $\begin{array}{l}\text { medium of communication } \\
\text { and cultural background }\end{array}$ & $\begin{array}{l}\text { Cao and Philp (2006); Kang (2005); Cao (2011); } \\
\text { Wen and Cle'ment (2003) }\end{array}$ \\
\hline 12 & Lesson content & $\begin{array}{l}\text { Cao and Philp (2006); Kang (2005); MacIntyre and } \\
\text { Legatto (2011) }\end{array}$ \\
\hline 13 & $\begin{array}{l}\text { attitudes toward the } \\
\text { learning situation }\end{array}$ & $\mathrm{Yu}, 2011$ \\
\hline 14 & $\begin{array}{l}\text { purposeful decisions in the } \\
\text { topic of the discussion }\end{array}$ & Zarrinabadi, Ketabi, and Abdi (2014) \\
\hline 15 & $\begin{array}{l}\text { Alignment with classroom } \\
\text { norms }\end{array}$ & Bernales (2016) \\
\hline 16 & Good group mates & Eddy-U (2015) \\
\hline 17 & teacher immediacy & Yu (2011) \\
\hline 18 & $\begin{array}{l}\text { Pattern of interaction } \\
\text { (teacher-fronted situation, } \\
\text { dyad, and small group }\end{array}$ & Cao and Philp (2006); Cao (2011); Cao (2006) \\
\hline 19 & The size of the group & $\begin{array}{l}\text { Cao and Philp (2006); Kang (2005); Cao (2011); } \\
\text { Wen and Cle'ment (2003); Zarrinabadi, Ketabi, Abdi } \\
(2014)\end{array}$ \\
\hline 20 & Type of task & Cao and Philp (2006) \\
\hline 21 & explicit corrective feedback & Tavakoli and Zarrinabadi (2018) \\
\hline 22 & Course evaluation criteria & J.-E. Peng (2012) \\
\hline 23 & integrativeness, & $\mathrm{Yu}(2011)$ \\
\hline 24 & instructor position & Zarrinabadi (2014) \\
\hline
\end{tabular}

Among the ten items selected, the two variables of "the size of the group" and "alignment with classroom norms" were given the most and the least important priorities of situational variables affecting L2WTC. In one questionnaire, the preference or priority of the most important factor over other factors and in another questionnaire, the priority of the least important variable over other variables was measured through paired comparison. In Table 2, the situational variables affecting L2WTC, which were selected by the experts, are shown. 
Table 2

L2WTC situational variables selected by the experts

\begin{tabular}{|c|l|c|l|}
\hline NO. & \multicolumn{1}{|c|}{ Factor } & NO. & \multicolumn{1}{|c|}{ Factor } \\
\hline 1 & The size of the group & 6 & $\begin{array}{l}\text { purposeful decisions in the topic of the } \\
\text { discussion }\end{array}$ \\
\hline 2 & $\begin{array}{l}\text { familiarity with topics } \\
\text { under discussion }\end{array}$ & 7 & attitudes toward the learning situation \\
\hline 3 & $\begin{array}{l}\text { Interlocutors and } \\
\text { familiarity with them }\end{array}$ & 8 & $\begin{array}{l}\text { Pattern of interaction (teacher-fronted } \\
\text { situation, dyad, and small group }\end{array}$ \\
\hline 4 & $\begin{array}{l}\text { explicit corrective } \\
\text { feedback }\end{array}$ & 9 & Course evaluation criteria \\
\hline 5 & Lesson content & 10 & Alignment with classroom norms \\
\hline
\end{tabular}

After calculating the geometric mean of the values obtained from the questionnaires, the following linear programming problem has been achieved.

$\min \xi$

s.t.

$\left|w_{B}-2.12 w_{2}\right| \leq \xi, \quad\left|w_{1}-8.87 w_{w}\right| \leq \xi$

$\left|w_{B}-3.43 w_{3}\right| \leq \xi, \quad\left|w_{2}-7.67 w_{w}\right| \leq \xi$

$\left|w_{B}-7.69 w_{4}\right| \leq \xi, \quad\left|w_{3}-6.73 w_{w}\right| \leq \xi$

$\left|w_{B}-4.21 w_{5}\right| \leq \xi, \quad\left|w_{4}-3.83 w_{w}\right| \leq \xi$

$\left|w_{B}-5.91 w_{6}\right| \leq \xi, \quad\left|w_{5}-6.74 w_{w}\right| \leq \xi$

$\left|w_{B}-7.68 w_{7}\right| \leq \xi, \quad\left|w_{6}-3.91 w_{w}\right| \leq \xi$

$\left|w_{B}-5.23 w_{8}\right| \leq \xi, \quad\left|w_{7}-2.69 w_{w}\right| \leq \xi$

$\left|w_{B}-7.75 w_{9}\right| \leq \xi, \quad\left|w_{8}-5.11 w_{w}\right| \leq \xi$

$\left|w_{B}-8.95 w_{10}\right| \leq \xi, \quad\left|w_{9}-2.31 w_{w}\right| \leq \xi$

$\sum_{j} w_{j}=1$

$w_{j} \geq 0$, for all $j$ 
To find the optimal solution for linear programming problem, the weight of each variable was determined. The relative importance (weight) and the priority of each variable are brought in Table 3 and Figure 2.

Table 3

The relative importance and prioritization of situational factors

\begin{tabular}{|c|c|c|c|c|}
\hline NO. & Factor & & $\begin{array}{l}\text { Relative } \\
\text { importance } \\
\text { (weight) }\end{array}$ & Rank \\
\hline 1 & The size of the group & $w_{1}^{*}$ & 0.202 & 1 \\
\hline 2 & $\begin{array}{l}\text { Familiarity with [topics under } \\
\text { discussion }\end{array}$ & $w_{2}^{*}$ & 0.167 & 2 \\
\hline 3 & Interlocutors and familiarity with them & $w_{3}^{*}$ & 0.118 & 3 \\
\hline 4 & Lesson content & $w_{4}^{*}$ & 0.101 & 7 \\
\hline 5 & Explicit corrective feedback & $w_{5}^{*}$ & 0.072 & 4 \\
\hline 6 & $\begin{array}{l}\text { Purposeful decisions in the topic of the } \\
\text { discussion }\end{array}$ & $w_{6}^{*}$ & 0.074 & 6 \\
\hline 7 & Attitudes toward the learning situation & $w_{7}^{*}$ & 0.063 & 8 \\
\hline 8 & $\begin{array}{l}\text { Pattern of interaction (teacher-fronted } \\
\text { situation, dyad, and small group }\end{array}$ & $w_{8}^{*}$ & 0.096 & 5 \\
\hline 9 & Course evaluation criteria & $w_{9}^{*}$ & 0.059 & 9 \\
\hline 10 & Alignment with classroom norms & $w_{10}^{*}$ & 0.048 & 10 \\
\hline
\end{tabular}

Figure 2

Weights of research variables 


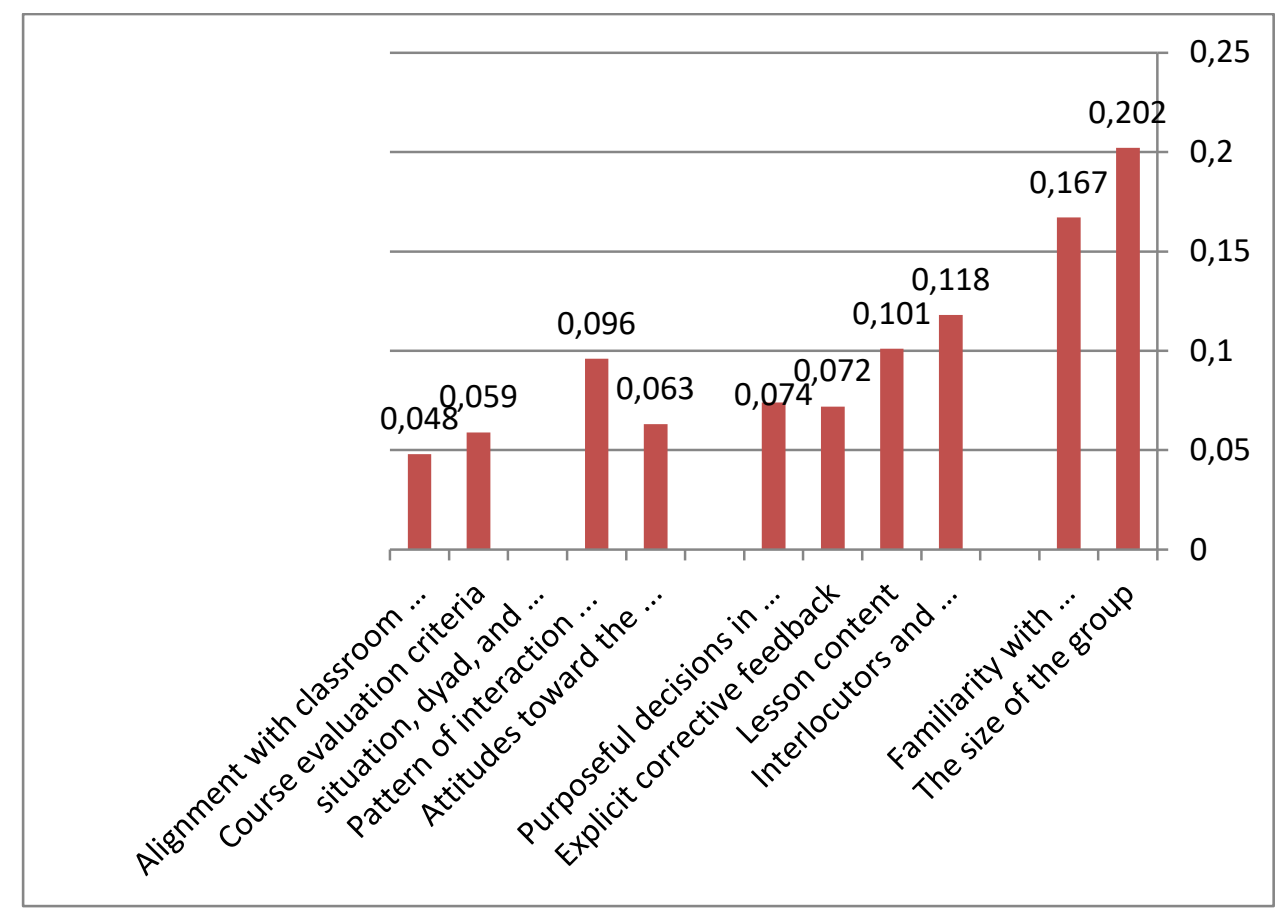

The findings in Table 3 and Figure 1 reveal that among the 10 situational variables which were investigated in the current study, "the size of the group", "familiarity with topics under discussion" and "interlocutors and familiarity with them" with the relative weights of $0.202,0.167$ and 0.118 , were given the first to third priorities, respectively. The priorities of other factors is as follows: "explicit and implicit corrective feedback" (the relative weight $=0.072)$ the fourth priority, "pattern of interaction (dyad, teacher-fronted situation and small group) (the relative weight $=0.096$ ) the fifth priority, "purposeful decisions on the topic of the discussion" (relative weight= 0.074) the sixth priority, "lesson content" (relative weight $=0.101$ ) the seventh priority, "attitudes toward the learning situation" (relative weight $=0.063$ ) the eighth priority, "course evaluation criteria" (relative weight $=0.059$ ) the ninth priority, and "alignment with classroom norms" (relative weight=0.048) the tenth and the last priority. The next part is concerned with the discussion related to the findings obtained.

\section{Discussion}


The present study was designed to determine the most and the least important situational variables affecting L2WTC from the viewpoint of a group of TEFL experts in Iran. After reviewing the related studies, 24 factors were found to be influential on L2WTC, as reported by L2 researchers in various L2 contexts. Using a screening questionnaire, the ten most-investigated factors were chosen to be ranked by $\mathrm{BW}$ multi-criteria decision-making method. The most interesting finding was that "the size of the group" was ranked to be the most important predictor of L2WTC. In accordance with the present result, previous studies have demonstrated that "group size" was among the main contextual and situational factors influencing WTC (Cao, 2011; Cao \& Philp, 2006; Kang, 2005; Wen \& Clément, 2003; Zarrinabadi et al., 2014). Small classes, as reported by Cooper and Robinson (2000), are the best alternative to create occasions for EFL learners to spend more times together in meaningful and active learning and thinking situations. Engaging students to work in small groups or dyads make the EFL teachers assured about the equal share of opportunities which would be given to their language learners. The small groups of students help to lessen the effect of stressful classroom atmosphere and lack of opportunities to talk to a great extent (Syed \& Kuzborska, 2018). One immediate result of talking in small groups is increasing the confidence in English communication (Yashima et al., 2004). Cao and Philp (2006) and de Saint Léger and Storch (2009) have also reported that learners believed whole-class discussions and interactions were more difficult to take part than small groups or dyadic discussions/interactions.

Another finding was that the two variables of "familiarity with topics under discussion" and "interlocutors and familiarity with them" were the other main situational predictors of L2WTC. The present findings seem to be consistent with other research which showed that situational WTC in L2 contexts emerge from the influence of various environmental factors including familiarity with topic under discussion and interlocutors 
(Cao \& Philp 2006; Kang, 2005; Cao, 2011; Wen \& Cle'ment, 2003). A possible explanation for this result may be that most EFL learners who do not have the chance to communicate outside L2 classrooms show more willingness to start communication in situations which had experienced before. Therefore, interactions in unfamiliar situations, such as public talk, is challenging and demanding (Vongsila \& Reinders, 2016). According to Kang (2005), two types of familiarity, context and receiver familiarity, are effective factors for initiation of L2 communication.

"Explicit corrective feedback" was found to be the other influential factor influencing L2WTC from the view point of TEFL experts. The findings of the current study are consistent with those of Tavakoli and Zarrinabadi (2016) who tried to investigate the influence of implicit and explicit corrective feedback on L2WTC. The results revealed that, while explicit corrective feedback enhanced L2WTC, implicit corrective feedback did not exert influence on it. The result of their study further supported the idea that explicit corrective feedback increased L2WTC through promoting their self-confidence. This result may be explained by the fact that, overall, corrective feedback is both helpful and essential for pushing language learners towards their L2 growth (Lyster, Saito, \& Sato, 2013). Previous studies have revealed that giving adequate and effective feedback lead to grammatical, phonological and morphological development in language learners (Rosa \& Leow, 2004).

As regards the least important, or the worst, predictors of L2WTC, the results of this study agree with the findings of other studies, in which "attitudes towards the learning situation" either does not predict L2WTC or is considered to be an indirect predictor of it. In light of this, MacIntyre and Charos (1996) examined a model of L2WTC, which was based on the socio-educational model of language learning proposed by Gardner and MacIntyre, (1993). Based on the suggested path model of L2WTC, "attitudes towards the learning 
situation" and "integrativeness" affect the learners' L2WTC indirectly through motivation. Yet in another study, which examined the relationship between L2WTC and integrative motivation, Peng (2007) found that "motivation" was one of the strongest predictors of L2WTC while "attitude towards the learning situation" did not predict it.

The current study found that "course evaluation criteria" was one of the least important, or one of the worst, predictors of L2WTC. However, this result has not previously been described. Applying Bronfenbrenner's (1999) nested ecosystems model as an analytical framework, Peng (2012) found that there were six types of factors underlying WTC in the microsystem including motivation, learner's beliefs, affective factors, cognitive factors, linguistic factors and classroom environment. At the exosystemic level, classroom setting, curriculum design and course evaluation criteria were perceived to be strongly related to WTC. At the interview sessions, the participants of study complained that their WTC dropped when their course schedule was overwhelming. This was because they had not prepared enough and could not respond to their teachers' prompts.

In this study, "alignment with the classroom norms" was found to be among the least important predictors of L2WTC. However, the findings of the current study do not support the previous research. Bernales (2016), for instance, applied a mixed-method study to investigate L2 use and classroom participation practices among German EFL learners. The researcher tried to find the learners' expectations and predictions regarding their participations during the L2 classes and the reasons behind their actions. In the stimulated recall interviews, the participants were required to explain their reasons for speaking or being silent at specific moments in the classroom. The results indicated that there was a link between predicted and self-reported participation that developed as the result of a combination of factors such as teacher's expectations, alignment with the classroom norms, students' speaking goals and their motivations among other. For example, learner participants 
stated that their speaking turns were mostly influenced by the norms which were set by their teachers.

\section{Conclusion}

The present study addressed the situational predictors of L2WTC which were reported in literature and had the attempt to prioritize the most and the least important ones. In doing so, the related literature was reviewed and one of the most recent multi-criteria decisionmaking methods, Best-worst method, was employed to prioritize the ten-selected variables. The findings indicated that "the size of the group", "familiarity with topics under discussion", "interlocutors and familiarity with them" and "explicit corrective feedback" received the first to fourth priority from the viewpoint of TEFL experts.

The findings of this study have some important implications for future practice of EFL teachers and researchers in the field. To language teachers, this study suggests that limiting the number of language learners in EFL classrooms, arranging classroom and discussion groups based on the language learners' preferences and familiarity and giving the topics of interests to language learners are among the best ways to generate situational L2WTC. The more the interaction environment and class atmosphere are safe for language learners, the higher their opportunities and excitements in a discussion group will become. The other major finding of this study was that giving explicit feedback can enhance the learners' interests in initiating an interaction. Consequently, it is suggested that language teachers provide as much feedback as possible to their learners to make them confident about progressing in the communication cycle. This will eventually lead to meaningful learning since learners can learn from their mistakes.

The generalizability of these results is subject to certain limitations. Although the researchers had the attempt to find all the situational factors reported in the literature, some of 
them might be hidden from the researchers' eyes. Further research in this field would be of great help in finding all factors and adding them to the present list. The present study had a quantitative framework using BWM to explore situational variables and their prioritization in Iranian EFL context. Using other analytic methods, such as ANP or DEMATL, which are used to explore the close relationships between criteria and build a network relation map for them, could be usefully explored in further research. The other major limitation of this study is that the findings might be of interest to Iranian teachers of English. More specifically, it's unclear whether the same L2WTC factors are at work in classrooms with instructors from a different culture and with a different L1.

List of abbreviations:

- Second language willingness to communicate (L2WTC)

- English as a Foreign Language (EFL)

- Second language (L2)

- Willingness to communicate (WTC)

- $\quad$ Teaching English as a Foreign Language (TEFL)

- Best-worst method (BWM)

- Analytic Hierarchy Process (AHP)

- Multi-criteria decision-making method (MCDM)

- Analytic network process (ANP)

Declarations:

- Availability of data and material

Authors are ready to make reproducible materials described in the manuscript, including new software, databases and all relevant raw data, freely available to any scientist wishing to use them, without breaching participant confidentiality. Authors make their new software, databases, application/tool described in the manuscript available for testing by reviewers in a way that preserves the reviewers' anonymity.

- Funding

No funding was used for this study.

- Competing interest 
The authors declare that they have no competing interests.

- Authors' contributions

The authors confirm contribution to the paper as follows: study conception and design: Rafiee and Abbasian-Naghneh; data collection: Rafiee; analysis and interpretation of results: Abbasian-Naghneh; draft manuscript preparation: Rafiee. All authors reviewed the results and approved the final version of the manuscript.

- Acknowledgements

Not applicable

\section{References}

Ahmad, W. N. K. W., Rezaei, J., Sadaghiani, S., \& Tavasszy, L. A. (2017). Evaluation of the external forces affecting the sustainability of oil and gas supply chain using Best Worst Method. Journal of cleaner production, 153, 242-252. doi:https://doi.org/10.1016/j.jclepro.2017.03.166

Ahmadi, H. B., Kusi-Sarpong, S., \& Rezaei, J. (2017). Assessing the social sustainability of supply chains using Best Worst Method. Resources, Conservation and Recycling, 126, 99-106. doi:https://doi.org/10.1016/j.resconrec.2017.07.020

Ajrina, A. S., Sarno, R., \& Ginardi, R. V. (2018). Comparison of AHP and BWM Methods Based on Geographic Information System for Determining Potential Zone of Pasir Batu Mining. Paper presented at the International Seminar on Application for Technology of Information and Communication .

Baker, S. C., \& MacIntyre, P. D. (2000). The role of gender and immersion in communication and second language orientations. Language learning, 50(2), 311341. doi:https://doi.org/10.1111/0023-8333.00224

Barjesteh, H., Vaseghi, R., \& Neissi, S. (2012). Iranian EFL learners' willingness to communicate across different context-and receiver-types. International Journal of English Linguistics, 2(1), 47. doi:https://doi.org/10.1016/j.sbspro.2014.03.502

Bernales, C. (2 (016Towards a comprehensive concept of willingness to communicate: Learners' predicted and self-reported participation in the foreign language classroom. System, 56, 1-12. doi:https://doi.org/10.1016/j.system.2015.11.002

Cao, Y. (2011). Investigating situational willingness to communicate within second language classrooms from an ecological perspective. System, 39(4), 468-479 . 
Cao, Y., \& Philp, J. (2006). Interactional context and willingness to communicate: A comparison of behavior in whole class, group and dyadic interaction. System, 34(4), 480-493. doi:https://doi.org/10.1016/j.system.2006.05.002

de Saint Léger, D., \& Storch, N. (2009). Learners' perceptions and attitudes: Implications for willingness to communicate in an L2 classroom. System, 37(2 .285-269, doi:https://doi.org/10.1016/j.system.2009.01.001

Dorman, J., Fisher, D., \& Waldrip, B. (2006). Learning environments, attitudes, efficacy and perceptions of assessment: A LISREL analysis. Contemporary approaches to research on learning environments, 1-28 .

Eddy-U, M. (2015). Motivation for participation or non-participation in group tasks: A dynamic systems model of task-situated willingness to communicate. System, 50, 4355. doi:https://doi.org/10.1016/j.system.2015.03.005

Gupta, H. (2018). Evaluating service quality of airline industry using hybrid best worst method and VIKOR. Journal of Air Transport Management, 68, 35-47. doi:https://doi.org/10.1016/j.jairtraman.2017.06.001

Gupta, H., \& Barua, M. K. (2016). Identifying enablers of technological innovation for Indian MSMEs using best-worst multi criteria decision making method. Technological $\begin{array}{llll}\text { Forecasting } \quad \text { and } \quad \text { Social } & \text { 69-79. }\end{array}$ doi:https://doi.org/10.1016/j.techfore.2016.03.028

Ho, W. (2008). Integrated analytic hierarchy process and its applications-A literature review. European Journal of operational research, 186(1), 211-228. doi:https://doi.org/10.1016/j.ejor.2007.01.004

Jennings, P. A., \& Greenberg, M. T. (2009). The prosocial classroom: Teacher social and emotional competence in relation to student and classroom outcomes. Review of educational research, 79(1), 491-525. doi:https://doi.org/10.3102/0034654308325693

Kang, S.-J. (2005). Dynamic emergence of situational willingness to communicate in a

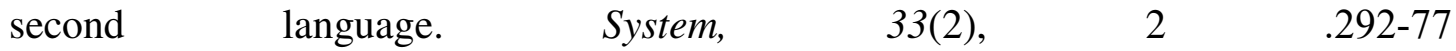
doi:https://doi.org/10.1016/j.system.2004.10.004

Khatib, M., \& Nourzadeh, S. (2015). Development and validation of an instructional willingness to communicate questionnaire. Journal of Multilingual and Multicultural Development, 36(3), 266-283. doi:https://doi.org/10.1080/01434632.2014.914523

Lyster, R., Saito, K., \& Sato, M. (2013). Oral corrective feedback in second language $\begin{array}{llll}\text { classrooms. } & \text { Language } & \text { teaching, } & \text { 46(1), }\end{array}$ doi:https://doi.org/10.1017/S0261444812000365 
MacIntyre, P. D., Baker, S. C ,.Clément, R., \& Conrod, S. (2001). Willingness to communicate, social support, and language-learning orientations of immersion students. Studies in second language acquisition, 23(3), 369-388. doi:https://doi.org/10.1017/S0272263101003035

MacIntyre, P. D „.Dörnyei, Z., Clément, R., \& Noels, K. A. (1998). Conceptualizing willingness to communicate in a L2: A situational model of L2 confidence and affiliation. The Modern Language Journal, 82(4), 545-562. doi: https://doi.org/10.1111/j.1540-4781.1998.tb05543.x

Mardani, A., Jusoh, A., \& Zavadskas, E. K. (2015). Fuzzy multiple criteria decision-making techniques and applications-Two decades review from 1994 to 2014. Expert systems with Applications, 42(8), 4126-4148. doi:https://doi.org/10.1016/j.eswa.2015.01.003

Peng, J.-E. (2012). Towards an ecological understanding of willingness to communicate in EFL classrooms in China. System, 40(2), 203-213. doi:https://doi.org/10.1016/j.system.2012.02.002

Peng, J. E., \& Woodrow, L. (2010). Willingness to communicate in English: A model in the Chinese EFL classroom context. Language learning, 60(4), 834-876. doi: https://doi.org/10.1111/j.1467-9922.2010.00576.x

Rafiee, M., \& Abbasian-Naghneh, S. (2018). Prioritization of critical individual factors influencing willingness to communicate: AHP method. Journal of Multilingual and Multicultural Development, 1-14. doi: DOI: 10.1080/01434632.2018.1521814

Ren, J., Liang, H., \& Chan, F. T. (2017). Urban sewage sludge, sustainability, and transition for Eco-City: Multi-criteria sustainability assessment of technologies based on bestworst method. Technological Forecasting and Social Change, 116, 29-39. doi:DOI: 10.1016/j.techfore.2016.10.070

Rezaei, J. (2015). Best-worst multi-criteria decision-making method. Omega, 53, 49-57. doi:https://doi.org/10.1016/j.omega.2014.11.009

Rezaei, J. (2016). Best-worst multi-criteria decision-making method: Some properties and a linear model. Omega, 64, 126-130 .

Rezaei, J., Hemmes, A., \& Tavasszy, L. (2017). Multi-criteria decision-making for complex bundling configurations in surface transportation of air freight. Journal of Air Transport Management, 61, 95-105. doi:https://doi.org/10.1016/j.jairtraman.2016.02.006

Rezaei, J., Nispeling, T., Sarkis, J., \& Tavasszy, L. (2016). A supplier selection life cycle approach integrating traditional and environmental criteria using the best worst 
method. Journal of cleaner production, 135, 577-588. doi:https://doi.org/10.1016/j.jclepro.2016.06.125

Rosa, E. M., \& Leow, R. P. (2004). Computerized task-based exposure, explicitness, type of feedback, and Spanish L2 development. The Modern Language Journal, 88(2), 192216. doi:https://doi.org/10.1111/j.0026-7902.2004.00225.x

Syed, H., \& Kuzborska, I. (2018). Dynamics of factors underlying willingness to communicate in a second language. The Language Learning Journal, 1-20. doi:https://doi.org/10.1080/09571736.2018.1435709

Tavakoli, M., \& Zarrinabadi, N. (2018). Differential effects of explicit and implicit corrective feedback on EFL learners' willingness to communicate. Innovation in Language Learning and Teaching, 247-259. doi:https://doi.org/10.1080/17501229.2016.1195391

Vongsila, V., \& Reinders, H. (2016). Making Asian learners talk: Encouraging willingness to $\begin{array}{lllll}\text { communicate. } & \text { RELC } & \text { Journal, }\end{array}$ https://doi.org/10.1177/0033688216645641

Wen, W.-P., \& Clément, R. (2003). A Chinese conceptualisation of willingness to communicate in ESL. Language Culture and Curriculum, 16(1), 18-38. doi:DOI: $10.1080 / 07908310308666654$

Yashima, T. (2012). Willingness to communicate: Momentary volition that results in L2 behaviour Psychology for language learning (pp. 119-135): Springer.

Yashima, T., Zenuk-Nishide, L., \& Shimizu, K. (2004). The influence of attitudes and affect on willingness to communicate and second language communication. Language learning, 54(1), 119-152. doi:DOI: 10.1111/j.1467-9922.2004.00250.x

$\mathrm{Yu}$, M. (2011). Effect of communication variables, affective variables, and teacher immediacy on willingness to communicate of foreign language learners. Chinese Journal of Communication, $\quad 4(02), \quad 218-236$. doi:https://doi.org/10.1080/17544750.2011.565678

Zarrinabadi, N. (2014). Communicating in a second language: Investigating the effect of teacher on learners' willingness to communicate. System, 42 .295-288, doi:http://dx.doi.org/10.1016/j.system.2013.12.014

Zarrinabadi, N., Ketabi, S., \& Abdi, R. (2014). Facilitating willingness to communicate in the second language classroom and beyond. The Clearing House: A Journal of Educational Strategies, Issues and Ideas, 87(5), 213-217. doi:DOI: $10.1080 / 00098655.2014 .924895$ 


\section{Appendices}

Appendix A: Paired comparison questionnaires

\begin{tabular}{|c|c|c|c|c|c|c|c|c|c|c|}
\hline \multicolumn{11}{|c|}{ The priority of the most important factor over other factors } \\
\hline Important Factor & & & & & & & & & & Other Factors \\
\hline The size of the group & 9 & 8 & 7 & 6 & 5 & 4 & 3 & 2 & 1 & $\begin{array}{l}\text { familiarity with topics under } \\
\text { discussion }\end{array}$ \\
\hline The size of the group & 9 & 8 & 7 & 6 & 5 & 4 & 3 & 2 & 1 & $\begin{array}{l}\text { Interlocutors and familiarity with } \\
\text { them }\end{array}$ \\
\hline The size of the group & 9 & 8 & 7 & 6 & 5 & 4 & 3 & 2 & 1 & $\begin{array}{l}\text { explicit and implicit corrective } \\
\text { feedback }\end{array}$ \\
\hline The size of the group & 9 & 8 & 7 & 6 & 5 & 4 & 3 & 2 & 1 & Lesson content \\
\hline The size of the group & 9 & 8 & 7 & 6 & 5 & 4 & 3 & 2 & 1 & $\begin{array}{l}\text { purposeful decisions in the topic } \\
\text { of the discussion }\end{array}$ \\
\hline The size of the group & 9 & 8 & 7 & 6 & 5 & 4 & 3 & 2 & 1 & $\begin{array}{l}\text { attitudes toward the learning } \\
\text { situation }\end{array}$ \\
\hline The size of the group & 9 & 8 & 7 & 6 & 5 & 4 & 3 & 2 & 1 & $\begin{array}{l}\text { Pattern of interaction (teacher- } \\
\text { fronted situation, dyad, and small } \\
\text { group }\end{array}$ \\
\hline The size of the group & 9 & 8 & 7 & 6 & 5 & 4 & 3 & 2 & 1 & Course evaluation criteria \\
\hline The size of the group & 9 & 8 & 7 & 6 & 5 & 4 & 3 & 2 & 1 & Alignment with classroom norms \\
\hline
\end{tabular}

\begin{tabular}{|l|l|l|l|l|l|l|l|l|l|l|}
\hline \multicolumn{8}{|c|}{ The priority of other factors over the least important factor } \\
\hline \multicolumn{1}{|c|}{ Other Factors } & \multicolumn{7}{|c|}{ Least important Factor } \\
\hline The size of the group & 9 & 8 & 7 & 6 & 5 & 4 & 3 & 2 & 1 & Alignment with classroom norms \\
\hline $\begin{array}{l}\text { familiarity with topics } \\
\text { under discussion }\end{array}$ & 9 & 8 & 7 & 6 & 5 & 4 & 3 & 2 & 1 & Alignment with classroom norms \\
\hline $\begin{array}{l}\text { Interlocutors and } \\
\text { familiarity with them }\end{array}$ & 9 & 8 & 7 & 6 & 5 & 4 & 3 & 2 & 1 & Alignment with classroom norms \\
\hline $\begin{array}{l}\text { explicit and implicit } \\
\text { corrective feedback }\end{array}$ & 9 & 8 & 7 & 6 & 5 & 4 & 3 & 2 & 1 & Alignment with classroom norms \\
\hline Lesson content & 9 & 8 & 7 & 6 & 5 & 4 & 3 & 2 & 1 & Alignment with classroom norms \\
\hline $\begin{array}{l}\text { purposeful decisions in } \\
\text { the topic of the discussion }\end{array}$ & 9 & 8 & 7 & 6 & 5 & 4 & 3 & 2 & 1 & Alignment with classroom norms \\
\hline $\begin{array}{l}\text { attitudes toward the } \\
\text { learning situation }\end{array}$ & 9 & 8 & 7 & 6 & 5 & 4 & 3 & 2 & 1 & Alignment with classroom norms \\
\hline $\begin{array}{l}\text { Pattern of interaction } \\
\text { (teacher-fronted situation, }\end{array}$ & 9 & 8 & 7 & 6 & 5 & 4 & 3 & 2 & 1 & Alignment with classroom norms \\
\hline
\end{tabular}


dyad, and small group

Course evaluation criteria \begin{tabular}{lllllllllllll}
9 & 8 & 7 & 6 & 5 & 4 & 3 & 2 & 1 & Alignment with classroom norms \\
\hline
\end{tabular}

Appendix B: Screening questionnaire distributed among the participants

\begin{tabular}{|c|c|c|c|c|c|c|}
\hline \multirow[t]{2}{*}{ No. } & \multirow[t]{2}{*}{ Situational Factors } & \multicolumn{5}{|c|}{ Degree of importance } \\
\hline & & 兽 & 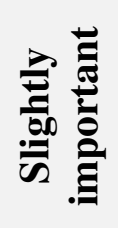 & 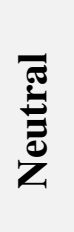 & 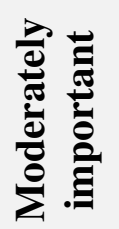 & 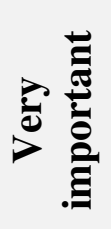 \\
\hline 1 & instrumental orientation & & & & & \\
\hline 2 & Task orientation & & & & & \\
\hline 3 & Where interactions occur & & & & & \\
\hline 4 & Interlocutors and familiarity with them & & & & & \\
\hline 5 & Context type & & & & & \\
\hline 6 & participation & & & & & \\
\hline 7 & teaching style & & & & & \\
\hline 8 & familiarity with topics under discussion & & & & & \\
\hline 9 & class dynamism & & & & & \\
\hline 10 & The issue of time & & & & & \\
\hline 11 & $\begin{array}{l}\text { medium of communication and cultural } \\
\text { background }\end{array}$ & & & & & \\
\hline 12 & Lesson content & & & & & \\
\hline 13 & attitudes toward the learning situation & & & & & \\
\hline 14 & $\begin{array}{l}\text { purposeful decisions in the topic of the } \\
\text { discussion }\end{array}$ & & & & & \\
\hline 15 & Alignment with classroom norms & & & & & \\
\hline 16 & Good group mates & & & & & \\
\hline 17 & teacher immediacy & & & & & \\
\hline 18 & $\begin{array}{l}\text { Pattern of interaction (teacher-fronted } \\
\text { situation, dyad, and small group }\end{array}$ & & & & & \\
\hline 19 & The size of the group & & & & & \\
\hline 20 & Type of task & & & & & \\
\hline
\end{tabular}




\begin{tabular}{|c|l|l|l|l|l|l|}
\hline 21 & explicit corrective feedback & & & & & \\
\hline 22 & Course evaluation criteria & & & & & \\
\hline 23 & Integrativeness, & & & & & \\
\hline 24 & Instructor position & & & & & \\
\hline
\end{tabular}

